\title{
都心部に設置した緑陰空間の暑熱期における 熱環境改善および医学的観点からの改善効果
}

Study on the Positive Effects of Creating Shaded Areas of Greenery in Urban Environments during the Hot Summer Season, both from the Perspective of Cooling the Environment itself and also from a Medical Perspective

\author{
手代木 純* 高柳 和江 ${ }^{* *}$ 井口 義也*** 狩谷 達之**** 半田真理子* \\ Jun TESHIROGI, Kazue TAKAYANAGI, Yoshiya IGUCHI, Tatsuyuki KARIYA, \\ Mariko Handa
}

\begin{abstract}
In order to verify the increased comfort level, which can be achieved by increasing the shade provided by greenery in urban areas, we conducted the following experiment in the summer of 2007 . We created a shaded green area in Tokyo with trees planted in containers, and measured the physiological and psychological effects on people and the cooling effect on the environment. When we measured the relative temperature before and after the installation (the green shaded area and the paving blocks) and compared the results inside the green shaded area against an un-shaded area, we found that a reduction of $2 \sim 3^{\circ} \mathrm{C}$ had been achieved. Furthermore, we carried out a physiological test of the effects on twenty subjects and by testing their saliva we found that there had been a notable decrease in the level of cortisol. In a mood-profiling test (Profile of Mood States) we found that the subjects' irritability and aggression scores were also significantly lower, when measured before and after, under the shaded green area. These results indicate that even with a small area of shaded greenery, a certain level of environmental cooling can be achieved and they also demonstrate that there is an improvement in the physiological and mental state of people living in urban environments, proving, therefore, with quantitative data that there is a possibility for green shaded areas to make city life more pleasant.
\end{abstract}

Keywords: Green Shade, Urban Area, Container Greening, Thermal Environment, cortisol, POMS キーワード：緑陰, 都市空間, コンテナ緑化, 熱環境, コルチゾール, 感情プロフィール検査

\section{1.はじめに}

日本の都市の緑被率は減少の一途をたどっている。たとえば名 古屋市の場合, 1990 年時点の $29.8 \%$ から, 以降 5 年拄きの調査 で $27.4 \%, 25.3 \%$, 最新の 2005 年調査で $24.8 \%$ ありり ${ }^{1)}$, 特に 民有地での減少が著しい2)。こうした状沉に対応すべく, 同市で は 2008 年 10 月より市内の地域別に最低緑化面積を定めた「緑化 地域制度」を導入するなど，新たな取り組みが行われつつある。

また現代はストレス社会ともいわれている。厚生労働省の調查 によれば労働者の強い不安, 悩み, ストレスを持つ割合は男性で $63.8 \%$, 男女合計で $61.5 \%$ に達しており ${ }^{3)}$, 特に労働者人口が集 中する都市部においては，緑によるストレス緩和効果が期待され ている。社会医学の分野では都市住民の健康と近隣の緑の存在の 関係性を見る研究がなされている。Takano ら ${ }^{4)}$ は東京都内に住 んでいた 75 歳以上の高齢者 3,144 人の居住空間に緑があるかど うかを調査し, さらにその 5 年後の健康状態を追跡調查した結果, 住んでいる場所の近くに緑がある人は，5年後の生存率がそうで ない人に比べて 1.03 倍から 1.24 倍高いことを示した。オランダ では Maas ら ${ }^{5)}$ が年齢, 社会経済階層居住地域（都市之郊外）の 異なる 25 万人に調查分析し, 生活圈での身近に存在する緑と住 民の健康に影響があることを明らかにした。ほかにも，公衆衛生 的見地から緑が都市空間に必要であるとする報告がある ${ }^{6) \sim 10}$

こうした中で, みどりの持つ効果を定量的に明らかにして，緑 化を推進しようとする動きが近年活発化してきており，ヒートア イランド対策や温暖化防止の観点からはすでに多くの知見が得ら れつつある。しかし緑化された場所での都市住民の快適性につい て, 人間の生理的データで検証されたケースは依然として実証例 がそしい ${ }^{11}$ のが現状である。

ストレスを表す指標として，唾液に含まれるコルチゾールは被
験者にストレスを与えずに測定できる方法であり，さらに SD 法 などの主観評価などを加えた研究が進められてきている。ストレ スの測定は本来，通常の生活環境や日常的な行動の中で比較する ことが望ましいが，これまでは脳波の計測など非日常的な計測装 置を用いたケースや，また何らかの運動などの動的ストレスを与 えて変化を見るケースが多い122。

緑の癒し効果が注目される中で, 代替医療や園芸療法, 森林セ ラピーなどの研究例はあるものの, 都市の緑化による研究では, 多田 ${ }^{13)}$ や Takayanagi $ら^{14)}$ による植物と人工物との生理及び心 理上の比較や，岩崎ら ${ }^{15)}$ の都市公園内の植栽の比較などの研究事 例が挙げられる程度である。また実験計測の都合で郊外部の都市 公園や圃場などが用いられるケースがほとんどであり，都心部の オープンスペースにおいて，特に高木の緑陰下における日常的な 行動の中で，落ち着いて過ごした前後で比較を行った研究例は見 られない。

そこで本研究では，これまでに明らかとなっていない，緑陰の ほとんど無い都心部に新たに緑陰を創出した場合，どの程度快適 性が向上するかを検証するため，コンテナ樹木等で構成された緑 陰空間を東京都心部に仮設した上で，緑陰による熱環境改善効果， 及び人的な生理および心理的効果を計測した。すなわち，緑陰下 で過ごす人々の快適性の変化について複合的な視点で明らかにし ようとしたものである。

この研究は，小規模な緑陰を創出することで，暑熱期の屋外の 熱環境改善効果と, 従来研究例がそしいとされる ${ }^{11}$ 緑陰創出によ る人体への快適性の改善効果を客観的，定量的デー夕に基づき示 すことを目的としている。この成果により, 緑陰創出の意義が見 いだされ，さらに，その取り組みが進められるための根拠となる ものと考える。

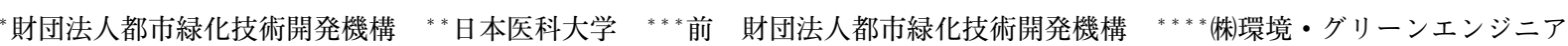


なおこの実験の生理・心理に関する調查研究については, （財）都市緑化技術開発機構倫理委員会（委員長 服部明世）の 審査を受け，2007 年第 1 号として承認された。

\section{2. 実験方法}

\section{(1) 緑陰の設置}

仮設的なコンテナ樹木と芝生による緑陰空間を，秋葉原駅西側 駅前広場（東京都千代田区外神田）に 2007 年 8 月 29 日 9 月 10 日の 13 日間, 設置した。レイアウトは, まとまった樹群(樹木 9 本)に囲まれた緑陰十芝生空間と, 樹木 3 本による緑陰, 芝生の みの空間と，タイプの異なった緑化空間とした（図－1）。

使用樹種は, 樹高 $5 \mathrm{~m}$ ・枝張り $2.5 \mathrm{~m}$ 内外の常緑樹 (シラカシ 4 本，クスノキ 1 本）と落葉樹（サルスベリ 2 本，サクラ類 2 本, ハナミズキ・ヒメシャラ・シナノキ各 1 本）計 12 本である。樹 木は幅 $1.6 \mathrm{~m} \times$ 奥行 $1.6 \mathrm{~m} \times$ 高さ $0.9 \mathrm{~m}$ のワイヤメッシュ製コンテ ナ（樹木固定装置内包）に設置した。また，コンテナ上部および エリア周縁を草花により縁取りして修景した。芝生は切芝のコウ ライシバを防水シート直上に設置した。設置面積は, 樹冠面積

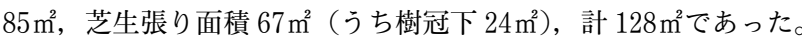
なお，このほかに休㮩施設としてコンテナ樹木周辺にベンチ 12 基を設置した。設置期間中は，利用者へのアンケート調査も実施 した。

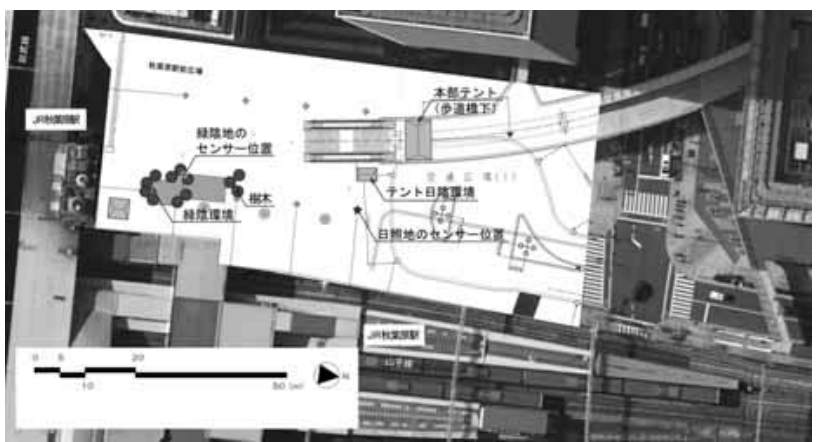

図一1 位置図
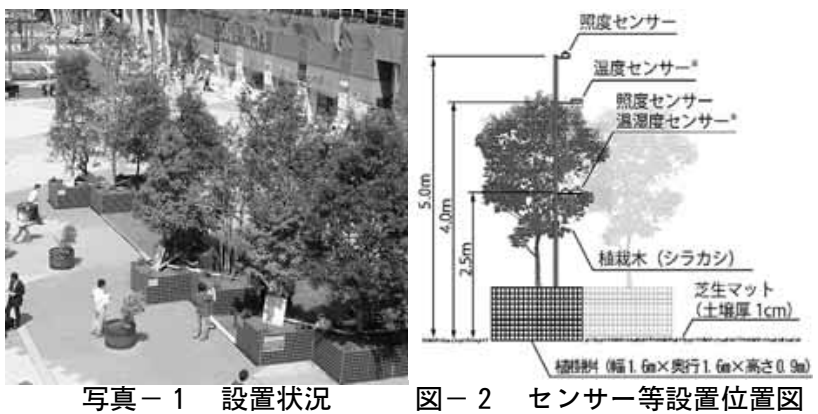

\section{（2）熱環境調査}

日向および緑陰下での気温, 湿度, WBGT (湿球黒球温度, 人体の熱収支に影響の大きい湿度・輻射熱・気温の 3 つを取り入 れた指標, 暑さ指数とも言う) 及び熱画像による表面温度などを 計測した (表 -1$)$ 。温度・湿度・日射量については設置期間中,

\section{表一1 熱環境調查の測定内容}

\begin{tabular}{|c|c|}
\hline 測定項目 & 測定位置 \\
\hline 度 & 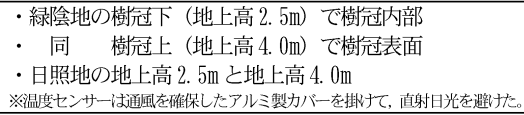 \\
\hline 湿 度 & 緑陰地の樹冠下，および日照地の地上高 2. 5m \\
\hline 照 度 & 緑陰地の樹冠下（地上高 $2.5 \mathrm{~m} ）$ と樹冠上（地上高 $5.0 \mathrm{~m}$ ) \\
\hline WBGT & $\begin{array}{l}\text { 緑陰地，および日照地 } 2 \text { 箇所の計 } 3 \text { 箇所 } \\
\text { 高さ } 0.8 \sim 1.2 \mathrm{~m} \text { の位置 }\end{array}$ \\
\hline
\end{tabular}

10 分おきの瞬時值を連続観測した。さらに特定日観測として, 期間中で最も晴天で高気温が観測された日であった 2007 年 9 月 8 日に, WBGT 值および熱画像の撮影を行った。

\section{（3）生理・心理効果調査}

(i ) 調査の概要と進め方

調査は 2007 年 9 月 9 日，健康な男女 20 名を 10 名づつの二組 に分けて，今回設置した緑陰環境と，同一広場内に設置した人工 的な日陰（テント内, 以下テント日院環境という）で, 午前 9 :

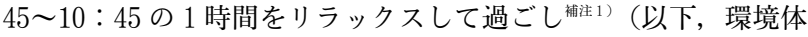
験という), その前後に実施した血圧・脈拍・呼吸数等の生理検 查，心身医学に基づく心理テスト，免疫系に関する唾液検査によ り，生理・心理効果について検証した。広場の滞在時間としては, 短時間での利用や長時間での利用が考えられるが，今回は二つの 環境による生理的・心理的効果の特性を把握することを目的とし ていることから， 既往研究 ${ }^{14)}$ より反応を捉えやすいとされる 1 時間を滞在時間とした。

(ii) 被験者の状況

被験者は，健康な 19-24 歳（平均年齢 21.09 歳）の男女の大学 生が対象である。男性 13 人 (平均 21.5 歳), 女性 7 人 (平均 19.7 歳）である。被験者の当日の行動は，朝食を摂らずに JR 秋 葉原駅改札口で集合した。インフォームドコンセントをして実験 の同意書を提出した後, 緑視を避けるため, アイマスクをつけて 西口広場の緑陰を見ないように歩道橋下の本部テント（前検查場 $3.6 \mathrm{~m} \times 5.4 \mathrm{~m})$ に移動した。

調査に先立ち, 被験者全員の疲労蓄積度を把握した。これは慢 性疲労により, 緑に対する反応が変わると考えられたためである。 調査では, 厚生労働省作成の労働者の疲労蓄積度自己診断チェッ クリスト ${ }^{16)}$ を使用し自己診断の上，点数化した。この結果に基づ き男女別平均值を算出し（男子 12.23 , 女子 15.00), 緑陰環境亡 テント日陰環境とで大きな差が出ないように, 被験者を割り振っ た。以下，緑陰環境下に配置された被験者群を緑陰群，テント内 に配置された被験者群をテント日陰群と呼ぶ（表一2）。

\section{表一 2 被験者の疲労蓄積度}

\begin{tabular}{|c|c|c|c|c|c|c|c|}
\hline \multicolumn{4}{|c|}{ 緑陰群 } & \multicolumn{4}{|c|}{ テント日陰群 } \\
\hline \multicolumn{2}{|c|}{ 男女別人数 } & 平均 & 平均疲労 & \multicolumn{2}{|c|}{ 男女別人数 } & 平均 & 平均疲労 \\
\hline 男 & 7 人 & 22.1 & 14.0 & 男 & 6 人 & 20.8 & 10.2 \\
\hline 女 & 3 人 & 19.3 & 12. 0 & 女 & 4 人 & 20.0 & 19.0 \\
\hline 計 & 10 人 & 21.3 & 13.4 & 計 & 10 人 & 20.5 & 13.7 \\
\hline
\end{tabular}

（iii）緑陰環境とテント日陰環境の状態

調查を実施した環境は，以下に示した二通りである。いずれも， 調査時間中は関係者以外の立ち入りを止め，被験者はそれぞれの 環境内に留まった。

(1)緑陰環境

緑陰環境の環境条件は，気温は $28.3 \sim 30.0^{\circ} \mathrm{C}$ 。樹冠内 $2.5 \mathrm{~m}$ の 高さの温度が $30.0^{\circ} \mathrm{C}$ ，湿度は $65 \%$ ，照度は $57 \sim 61 \mathrm{klx}$ であった。 (2)テント日陰環境

$1.8 \mathrm{~m} \times 3.6 \mathrm{~m}$ のテントをテント日陰環境とした。樹木の視覚的 影響を取り除くため, 被験者をテント内に座らせた。階段側の壁
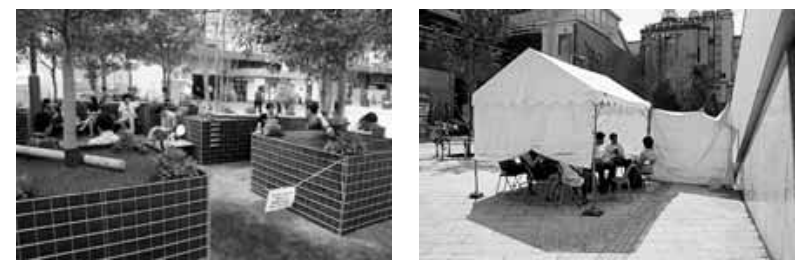

写真ー２＼cjkstart緑陰環境(左)とテント日陰環境（右） 
が見える一面を除き，三方にテント幕を下ろしたが，風通しを良 くするため, テント下方 $1 \mathrm{~m}$ を開けた。天井・壁共に, 白い帆布 で囲われた環境である。テント内気温は $32.0 \sim 33.0^{\circ} \mathrm{C}$, テント外 で日向の高さ $2.5 \mathrm{~m}$ の気温は $33.0 \sim 34.0^{\circ} \mathrm{C}$, 湿度は $55 \sim 60 \%$, 照 度は80〜87klx であった。

(iv) 調査項目とその内容

(1)生理検査

自律神経機能の活動を反映する指標として血圧・脈拍・呼吸数 を看護師により測定した。血圧は収縮期血圧（最高血圧）と拡張 期血圧（最低血圧）を，呼吸数は 30 秒間の呼吸数を測定した。

(2)心理検查 -1 (POMS)

POMS (Profile of Mood States, 感情プロフィール検査) は, 個人の気分状態や感情状態について，「緊張一不安」「抑うつ一落 ち込み」「怒り一敵意」「活気」「疲労」「混乱」の六つの尺度から 測定するように作成された検査である。

(3)心理検査 -2 (ワルテッグ描画テスト)

心理的な変化を描画により検査するため, ワルテッグ描画テス 卜を行った ${ }^{17)}$ 。テスト用紙は, 八つの太い黒枠で区切られた領域 があり，そこに様々な刺激図形が描かれている。この図に対し， 被験者がごのような印象を持ち，何を描画するかを見ることによ り，被験者の反応や態度を理解するものである。

(4)唾液コルチゾール検査

ストレスがあると, 扁桃体の不安中枢が活性化して, 視床下部 からの刺激で, 副腎からストレスホルモンであるコルチゾールが 高まるとされており, 唾液コルチゾール検査により, ストレスの 強弱が判断できる。本調査では, ガム状の採取器を 5 分間噛み, これを 30 分以内に専門業者により分離・採取し，測定した。

\section{3. 実験結果}

（1）熱環境調查

（i ）小規模な樹群による気温の低減効果

調査の結果, 今回設置した緑陰では, 日向の環境と比べて日中 で最大 $3^{\circ} \mathrm{C}$ 強, 概ね $2 \sim 3^{\circ} \mathrm{C}$ 気温低減効果が確認された (図- 3 )。

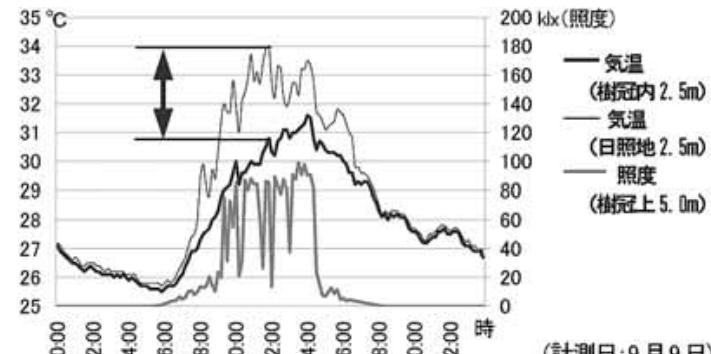

図一3 緑陰(地上 $2.5 \mathrm{~m}$ ) と日向の地上 $2.5 \mathrm{~m}$ の気温

（ii）熱中症の予防対策効果

調査日の午後から実施した WBGT の計測結果では, 日向の WBGT $\left({ }^{\circ} \mathrm{C}\right)$

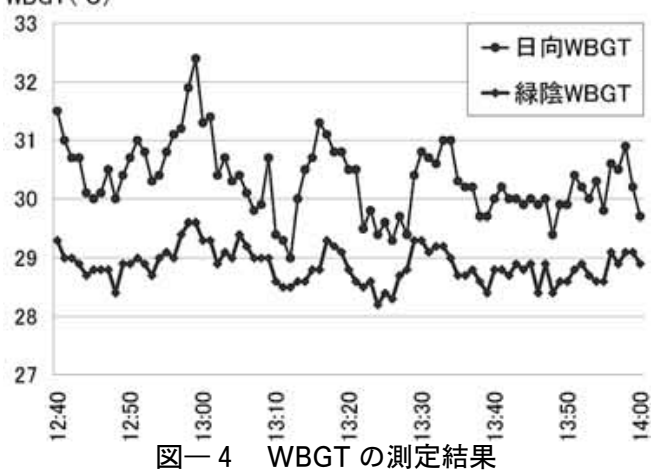

WBGT が 31〜 32 $\mathrm{C}$ に達して熱中症の危険性が非常に高い状態だっ たのに対し，緑陰では常に日向より低い $29^{\circ} \mathrm{C}$ 内外を推移した。 また, 風の影響により, 日向の值は大きく変動したが, 緑陰での 変動は日向に比べて小さかった(図－4)。

(iii) 熱画像による表面温度低減効果

緑陰の設置前（8月 27 日）と設置後（9月 4 日，いずれも晴天） を比較すると, 表面温度で最大 $11^{\circ} \mathrm{C}$ 程度の差が認められ, 仮設 的な小規模な緑陰でも，十分な表面温度低減効果があることが確 認された。なお, これらの熱環境に係る効果は, 緑陰の蒸散によ る効果と日射を遮ることにより日院となったことで得られた効果 による気温低減効果が重なって現れたものと考えられる。

\section{(2) 生理・心理効果検査}

(i) 生理検查

環境体験前後の収縮期血圧・拡張期血圧・脈拍・呼吸数では, 個々のデー夕は等分散性が認められた（Levene の検定による有 意確率 $\mathrm{p}>0.05 ＼mathrm{~ も の の, ~ 環 境 体 験 前 後 の 比 較 や, ~ ク ゙ ル ー フ ゚ 毎 の ~}$ 比較では統計的に有意差のある結果は得られなかった。しかし, いずれのデー夕も緑陰群で環境体験による值の低下が確認できた。 特に, 収縮期血圧と拡張期血压の差である脈圧は, テント日陰群 に比へて緑陰群の方が少なくなり, 自律神経が安定したと考えら れた（表一3）。

$$
\text { 表一 } 3 \text { 脈圧の変化 }(\mathrm{mg} / \mathrm{kg})
$$

\begin{tabular}{|c|c|c|}
\hline & 環境体験前 & 環境体験後 \\
\hline 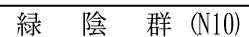 & 46.8 & 44.8 \\
\hline テント日陰 群 (N10) & 42.4 & 42.7 \\
\hline
\end{tabular}

（ii）心理検査 -1 (POMS)

環境体験の前後の平均值の差と, $\mathrm{t}$ 検定の結果である $\mathrm{t}$ 值と, 有意水準を，表 -4 に示した。この結果，緑陰群では，環境体験 前後で,「怒り一敵意」尺度の平均得点が $1 \%$ 水準で有意に減少 したことが確認された。しかし, 緑陰群・テント日陰群ともに, その他五つの尺度に有意な差は見られなかった（表一4）。

\section{表 -4 POMS 緑陰群前後間得点の比較}

\begin{tabular}{|l|c|r|r|r|r|r|}
\hline & $\begin{array}{c}\text { 緊張 } \\
\text { 不安 }\end{array}$ & $\begin{array}{c}\text { 抑うつ } \\
\text { 落ち込み }\end{array}$ & $\begin{array}{l}\text { 怒り- } \\
\text { 敵意 }\end{array}$ & 活気 & 疲労 & 混乱 \\
\hline 平均値 & -4.50 & -3.30 & -6.00 & 1.80 & -1.70 & -2.90 \\
\hline $\mathrm{t}$ 值 & 1.664 & 1.394 & 3.265 & -0.980 & 0.612 & 0.187 \\
\hline 有意水準 & 0.065 & 0.088 & 0.005 & 0.176 & 0.278 & 1.833 \\
\hline
\end{tabular}

(iii）心理検査 -2 (ワルテッグ描画テスト)

環境体験前後の描画状況を比較して, 図に書き加えられた変化 の数を主体とした量的分析では, 変化の総数については緑陰群と テント日陰群で差はなかった。しかし, 刺激図の内容に応じた変 化では, 緑陰群は大きな変化はなかったが, テント日陰群は反応 が減少した。

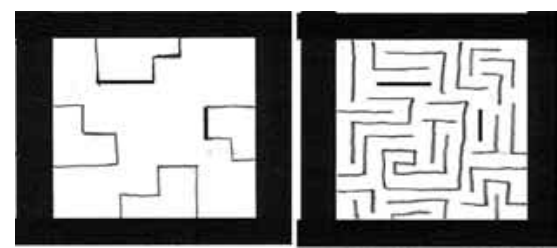

幾何学的な直線の みで構成され，思 考の柔軟性は見ら れない。迷路は不U 久の象徵であり, 後 の絵は偏執的な性 向も見られる。

図－５ テント日陰群の環境体験前後の描画（左が前, 右が後）

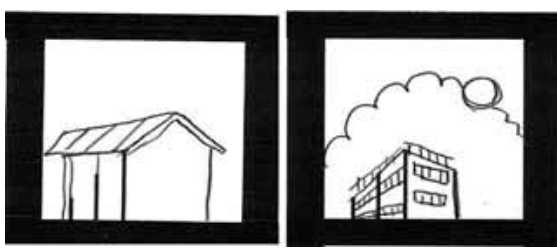

直線のみの絵が 体験後は曲線が加 わり, 柔軟性が出 てきただけでなく, 視点が広がってい ることが読みとれ る。

図-6 緑陰群の環境体験前後の描画（左が前, 右が後） 
次に，図として描かれた内容を中心とする質的分析では，テン 卜日陰群のほとんどがマイナス方向への変化したのに対し, 緑陰 群はプラスの変化を示した例が多かった（図一5，6）。

（iv）唾液コルチゾール検査

唾液コルチゾールに関する個々のデー夕は等分散性が認められ た (Levene の検定による有意確率 $\mathrm{p}>0.05)$ 。環境体験前後の比 較では, 両者とも值の低下が認められたものの, 緑陰群は環境体 験により唾液コルチゾールが統計的に有意 $(\mathrm{p}<0.05)$ に減り, テント日陰群と比較して減少率が高かった。これに対し, テント 日陰群は減少が認められるものの，統計的な有意ではなかった （p>0.05）（表一5）。

$$
\text { 表 }-5 \quad \text { 唾液コルチゾールの変化 }(\mu \mathrm{g} / \mathrm{d} \ell)
$$

\begin{tabular}{|l|r|r|c|}
\hline & 環境体験前 & 環境体験後 & $\begin{array}{c}\text { 有意確率 } \\
\text { (両側) }\end{array}$ \\
\hline 緑 陰 群 $(\mathrm{N} 10)$ & $0595 \pm 0.27$ & $0.323 \pm 0.10$ & $\mathrm{p}=0.012$ \\
\hline テント日陰群(N10) & $0.634 \pm 0.22$ & $0.459 \pm 0.18$ & $\mathrm{p}=0.087$ \\
\hline
\end{tabular}

\section{4. 考察}

\section{(1) 緑陰の設置で得られた効果}

コンテナ樹木による高さ $5 \mathrm{~m}$ 内外の樹木 9 本からなる $120 \mathrm{~m}^{2}$ 程 度の小規模な緑陰の設置により, 気温や表面温度が低減し, 地面 に植栽された通常の植栽と同程度の熱環境改善効果が確認できた。 また，仮設的設置でも十分な効果が確認されたことにより，夏場 に限定した緑陰の設置など，導入範囲の拡大をも示唆する結果と なったと考えられる。

\section{（2）生理・心理調査で得られた効果}

被験者による生理・心理に関する調査の結果より, 緑陰環境で 過ごした場合はストレスホルモンである唾液コルチゾールが統計 的に有意に減っていた。

POMS においては緑陰群では「怒り一敵意」を緩和させる効 果があることが検証された（p<.01）。ただしいずれの環境下でも その他五つの尺度に有意な差は見られなかった。この点について， 実験時期が暑熱期でいずれの環境においても暑かったこと, また 実験場所が駅前広場であり, 電車の走行音や駅・商業施設からの 騒音の繰り返しによる影響が考えられた。

今回の実験場所は, 周辺にほとんど公園の無い秋葉原地区を選 定した維 2 。商業地区に立地する緑化の少ない駅前広場としての 典型例と考えられる。

なお，設置期間中，緑陰空間利用者に取ったアンケート $(\mathrm{N}=$ 685）で，「緑陰空間は都市のどこにあるとよいか」の問いでは, 駅前広場が群を抜き(83.2\%), 次いでビルの回り $(61.6 \%)$, 道 路の歩道等(38.7\%), などとなった。この問いには, アンケート を実施した場所の印象が色濃く反映されたと考えられるが，市民 が日常的に利用する公的な空間への緑陰を求める割合が高いと考 えられる。

\section{5. まとめ, 今後の課題}

本研究では，小規模な緑陰における熱環境改善効果および生理・ 心理効果について検証した。この結果から，小規模な緑陰空間で あっても熱環境改善が図られ, かつ住まう都市住民の生理・心理 効果が向上する一端を示すことができ, 緑陰が快適性の向上に資 する緑陰が快適性の向上に資する可能性が定量的デー夕により示 唆された。

特に, 生理・心理効果測定の結果から, 都市の緑陰環境に身を 置くことで, 都市住民のストレスを軽減し, 疲労感を減らすこと ができる可能性が示唆された。

高柳 ${ }^{18)}$ は，都市空間に緑陰環境を設置することにより，予防的 リラックス効果で，医療費削減につながる可能性を指摘している。
こうした点も含め，都市の緑陰環境の創出により，熱環境改善 効果のみならず，ストレスの軽減に果たす役割など，多様な観点 で緑陰の創出による評価ができるよう，都市住民の生理的，心理 的効果に関する知見をさらに蓄積していくことが重要である。

謝辞：この実験は，国土交通省から（財）都市緑化技術開発機構 が受託した調査において行われた成果の一部である。本研究の実 施にあたり，調査協力を頂いた関係者および被験者の方々，熱環 境データの分析についてご示唆を頂いた和歌山大学山田宏之准教 授に感謝の意を表します。

\section{補注}

補注 1）1 時間の環境体験の中で, 都市環境や通常の広場にいる時に日常 的に行われていると考えられる行為のうち，携帯ゲーム機の使用 と携帯電話による通話は，他の被験者にストレス等の影響を及ほ す危険性と, 被験者が心理的に没頭して環境影響がなくなる可能 性があった為に禁止したが，携帯電話機器を使用した電子メール の送受信は他の被験者に及ぼす影響が少ないため許可した。また 被験者同士での会話は可とした。なおテント日陰群は，常に日陰 に設置された椅子に座っており，被験者の移動はなかったが，緑 陰群は日陰の移動に伴い，適宜座るベンチを移動した。

補注 2 ）駅を挟んで反対側 $250 \mathrm{~m}$ 先に一力所，線路を潜らずに到達できる 公園が $400 \mathrm{~m}$ 先に一カ所ある。

\section{引用文献}

1 ) 名古屋市 (2006) : 名古屋市のみどり 緑の現況調查報告書, $164 \mathrm{pp}$

2 ）（財）都市緑化技術開発機構編集 (2006)：緑の都市再生ガイドブック ーこうすればできる緑のネットワークー:ぎょうせい, $168 \mathrm{pp}$

3) 平成 14 年労働者健康状況調查の概要 (2003) 厚生労働省ホームペー シ <http://www.mhlw.go.jp/toukei/itiran/roudou/saigai/anzen/ kenkou02/index.html>, 2003.8 更新, 2008.9.23 参照

4) Takano T, Nakamura K, Watanabe M.(2002) : Urban residential environments and senior citizens' longevity in megacity areas: the importance of walkable green spaces. : J Epidemiol Community Health. 56(12):913-918

5 ) Maas J, Verheij RA, Groenewegen PP, de Vries S, Spreeuwenberg P.(2006) : Green space, urbanity, and health: how strong is the relation? : J Epidemiol Community Health. 60(7):587-592

6 ) Baum F. (2002): Health and greening the city; setting for health promotion : J Epidemiol Community Health. 56(12):897-898

7 ) Duhl L. (2002): Health and greening the city; relation of urban planning and health. : J Epidemiol Community Health. $56(12): 897$

8 ) Ashton JR. (2002) : Health and greening the city. : J Epidemiol Community Health. 56(12):896

9 ) McKenna J. (2002) : Health and greening the city; new visions for health promoters. : J Epidemiol Community Health. 56(12):896

10) Laraque D, Barlow B, Durkin M, Heagarty M. (1995) : Injury prevention in an urban setting: challenges and successes. : Bull N Y Acad Med. 72(1):16-30

11）岩崎寬 (2006)：都市公園における植栽樹のストレス緩和効果，造園分 野における人の健康と緑の効果に関する取り組み: ランドスケープ研 究 70(2), 147-149

12）加藤みわ子・伊藤康宏・永忍夫・清水遵(2006)：軽度の運動が慢性 ストレスにおよぼす影響について-唾液中 Cortisol 濃度, 気分評定に よる検討 : : 生物試料分析 29(2)，146-150

13）多田 充・藤井 英二郎 (2006)：生理・心理的応答加らみた緑陰の視覚 的快適性：ランドスケープ研究 69(5), 475-478

14) Takayanagi Y, Hagihara Y (2005): To Extend Health Resources in a Forested Hospital Environment - A Comparison Between Artificial and Natural Plants-：日本未病システム学会雑誌, 11(2)： $247-259$

15）岩崎 寬・山本 聡・石井麻有子・渡邊幹夫 (2007)：都市公園内の芝 生地およびラベンダー畑が保有する生理・心理的効果に関する研究： 緑化工学会誌 33(1), 116-121

16）労働者の疲労蓄積度自己診断チェックリストの公開について (2003) 厚生労働省ホームページ <http://www.mhlw.go.jp/houdou/2003/ 05/dl/h0520-3a.pdf>，2003.6.23 更新，2008.9.11 参照

17）ウルスラ・アヴェ=ラルマン/著 高辻玲子ら投影描画法テスト研究 会/責任編集（2002）：ワルテッグ描画テスト一心理相談のための一： 川島書店, 197-200

18）高柳 和江 (2008)：都市空間に㧍ける緑陰の効果一生理的，心理的, 身体的分析一：日本補完代替医療学会誌 5(2), 145-152 